\title{
Self-reported Attributes of Police-chiefs Compared to Civil Leadership: Inner drive, Tolerance to stress and Enterprise
}

\author{
Ann-Christine Andersson Arnten ${ }^{1}$, Bengt Jansson ${ }^{2}$, Klaus Olsen ${ }^{3}$ and Trevor Archer ${ }^{2}$ \\ ${ }^{1}$ Swedish Police, Department of National Operations, Assessment Functions, Stockholm, Sweden \\ ${ }^{2}$ University of Gothenburg, Department of Psychology, Gothenburg, Sweden \\ 3 JobMatchTalent, Gothenburg, Sweden
}

Corresponding author: Ann-Christine Andersson Arntén, Swedish Police, Department of National Operations, Assessment Functions, 10226 Stockholm, Sweden, Tel: 0722027660; E-mail: acarnten@gmail.com

Received date: December 16, 2016; Accepted date: January 23, 2017; Published date: January 30, 2017

Copyright: (C) 2017 Arnten AA, et al. This is an open-access article distributed under the terms of the Creative Commons Attribution License, which permits unrestricted use, distribution, and reproduction in any medium, provided the original author and source are credited.

\begin{abstract}
There is a tendency to regard police-work, implying independence and initiative in the absence of direct presence of authority that places a premium upon leadership, as a 'drudge' although 'daily hassles' may be converted immediately to "special events". Despite this aspect, police leadership tends not to differ from other, civil, forms of leadership. A sample of police leaders $(n=106)$ was compared to civil leaders derived from government administration and private enterprise $(n=1650)$. Personal attitudes to and experiences of job relations and characteristics are measured with the JMT three subscales (Inner Drive and Tolerance to stress distress from the main scale Stability together with Enterprise from the main scale Action) all of which provide an indication of the leader's resourcefulness. Low-level scoring on any of these three attributes is expected to induce negative influences upon subordinates whereas the opposite outcomes may be predicted by high-level scoring. The results indicated that: (i) All-level police chiefs differed markedly from executive leaders in public administration and private enterprise; the former expressed the lowest levels of tolerance to stress, enterprise and Inner drive. (ii) Correlational analyses indicated that there were clear-cut, positive and strong relationships between the three variables, tolerance to stress, enterprise and Inner drive. (iii) there was a marked difference between public and private executive leaders with regard to enterprise and Inner drive to the advantage of the private executive leaders. The present results are discussed in relation to police leadership inadequacy and efforts to overcome the situation.
\end{abstract}

Keywords: Police; Civil; Leaders; Inner drive; Tolerance to stress; Enterprise; coaching

\section{Introduction}

Policing as a career occupation presents a complex interaction of social, political and administrative assignments with expected performance in a myriad of sometimes difficult situations. Nevertheless, 'police-work' tends overwhelmingly to be regarded as week-day occupation, although the week-day aspect may rapidly emerge as a "special event". Police-work implies independence and initiative in the absence of any direct presence of authority thereby placing a demand upon personal leadership qualities in environments under continual change. Despite this requirement, police leadership tends not to differ from other, civil, forms although the situation insists upon a scenario of personal participation, fairness and understanding (Sir Ian Blair, previously Chief Constable and Deputy Commissioner, London [1]. Though obvious, leadership determines success [2,3] and is the major determinant of high-level performance [3-5].

The 'driving-force' and intrinsic motivation of leaders is associated positively with activity, stamina, creative problem-solving and positive emotions [6] implying that an excess of the former facilitates the leadership role. In compliance-enhancing organizations, such as the military and police, intrinsic motivation contributes to guidance and direction of employees, without overly controlling and restricting subordinate behavior when exposed to external uncertainty [7]. Under these conditions, the leader must be experienced and above the pressures exerted by current and up-coming environments evoking loyalty, commitment, and rules or routines that could be perceived as enabling rather than restrictive. Within a spectrum of leadershipevoking contexts, several attributes may be assumed to characterize necessary qualities for successful performance: these include inner drive, tolerance to stress and enterprise ("get-up-and-go") all of which provide an indication of the leader's resourcefulness. Low-level scoring on any of these three attributes is expected to induce negative influences upon subordinates whereas the opposite outcomes may be predicted by high-level scoring [8]. Low levels of stress tolerance imply a greater focus upon oneself to the exclusion of colleagues and subordinates [9] thereby invoking a deterioration of leadership capacity. High levels of job-stress and/or low capacity for stress tolerance influence creativity, efficacy, productivity and quality-ofperformance [10,7]. Low stress tolerance is associated with low energy, low positive affect and low optimism [11], all of which are linked to low social status [12]. Leaders who exhibit emotional stability present a calm composure in the face of work pressures and/or crises, show patience with subordinates' development and thrive on setbacks [13].

Enterprise ("get-up-and-go") is associated with achievement, drive, positive affect, intrinsic motivation and energy [14]. Enterprising individuals induce activity and movement in others since energy, whether positive or negative is infectious, thereby reinforcing the leader's enterprise as a positive influence. High achievement levels, reflected by leaders, sustain high levels for subordinates also and create opportunities. Through goal-images and visions can the leader create a clear picture of the 'work-reality' with reduced risk for uncertainty and 
worry [15]. High levels of enterprise block tendencies for resignation and submissiveness in the face of adversity and instead reflect the desire to continue. Among patients presenting chronic heart disease, an enterprising outlook seems essential to satisfactory prognosis [16].

The purpose of the present study was to ascertain the extent to which the self-reported responses of all-level leaders selected from the Swedish Police Corps matched those of all-level leaders from public administration and private enterprises.

\section{Method}

\section{Design}

A cross-sectional design was used to compare police leaders with chosen reference groupings from a norm group of leaders, who provided self-reports at time of recruitment by use of an inventory [17]. Measures were concerned with personal features, attitudes and experiences of work life.

\section{Participants: Sample and reference groups}

A sample of police leaders $(n=106)$ with mixed experience from leadership was compared to other groupings [18]. The criteria used for selection of reference groupings were (a) homogeneity as to occupational orientation, (b) private or public employment, and (c) variation of level of position (low, medium, high). The last two criteria crossed gave rise to six reference groupings $(n=1650)$. Thus, the whole group included 1756 cases.

\section{The Job Match Talent (JMT) inventory}

Personal attitudes to and experiences of job relations and characteristics are measured with the JMT. The JMT test is based on ten main scales, each presenting three subscales [19].

In this study, three subscales (Inner Drive and Tolerance to stress from the main scale "Stability" together with Enterprise from the main scale "Action") were used. The subscales were chosen as they are attributes important for their representation of an open, supportive and flexible leadership that is sustainable even in stressful circumstance.

\section{Statistical procedure}

The comparisons of the police leaders to reference leader groups were performed with planned comparisons (based on analysis of variance). Three contrasts of leaders were of interest: (i) Police Vs. Public, (ii) Police Vs. Private, and, for control of the reference groupings, (iii) Public Vs. Private.

\section{Results}

For the three scales (Inner drive, Tolerance to stress, and Enterprise), the ratings by the police leaders were significantly lower ( $\mathrm{p}<0.05$ to 0.01 ) than the corresponding ratings by the two reference groupings. Furthermore, the contrast between public and private leaders was significant for Inner drive (Public ratings higher, $\mathrm{p}<0.01$ ) and Enterprise (Public ratings lower, $\mathrm{p}<0.01$ ), but not for the Tolerance to stress. See Figure below for an overview of the differences.

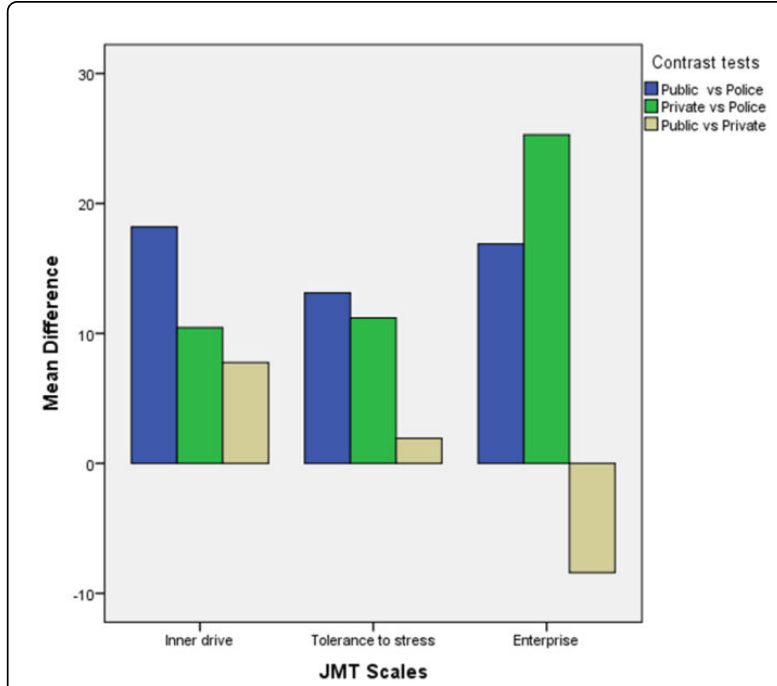

Figure 1: Mean differences for JMT attributes, Inner drive, Tolerance to stress and Enterprise, between police leaders $(n=106)$ and the reference groups of public $(\mathrm{n}=822)$ and private leaders $(\mathrm{n}=828)$, respectively. For all three JMT scales, the police ratings were significantly lower than the ratings by the reference groups $(\mathrm{p}<0.05$ to 0.01$)$. Contrasts between public and private leaders were significant for Inner drive and Enterprise $(\mathrm{p}<0.01)$, but not for Tolerance to stress.

The six correlations between Inner drive and either Tolerance to stress or Enterprise, ranged between 0.49 to 0.59 across the three groupings of leaders (Police, Public, Private). These correlations were rather invariant across groupings. Moreover, Tolerance to stress and Enterprise was non-correlated across all three groupings (Table 1).

\begin{tabular}{|l|l|l|l|l|l|l|l|l|l|l|l|l|}
\hline & \multicolumn{3}{|l|}{ Police leaders } & & \multicolumn{3}{|l|}{ Police leaders } & \multicolumn{3}{|l|}{ Police leaders } \\
\hline & B & C & F & & B & C & F & & B & C & F \\
\hline B & 1 & & & B & 1 & & & B & 1 & & \\
\hline C & $0.50^{* *}$ & 1 & & C & $0.53^{* *}$ & 1 & & C & $0.51^{* *}$ & 1 & \\
\hline F & $0.59^{* *}$ & 0.04 & 1 & F & $0.51^{* *}$ & 0.03 & 1 & F & $0.49^{* *}$ & 0.01 & 1 \\
\hline
\end{tabular}

JMT: Job Match Talent; B: Inner drive; C: Tolerance to stress; F: Enterprise; **: $p<0.01$

Table 1: Correlation coefficients among three JMT scales, Inner drive, Tolerance to stress and Enterprise, across police leaders $(n=106)$ and the reference groups of public $(\mathrm{n}=822)$ and private leaders $(\mathrm{n}=828)$, respectively $(\mathrm{N}=1756)$.

\section{Discussion}

The present findings may be summarised as follows: (i) all-level police chiefs differed markedly from executive leaders in public administration and private enterprise; the former expressed the lowest levels of tolerance to stress, enterprise and Inner drive. (ii) Correlational analyses indicated that there were clear-cut, positive and strong relationships between the three variables, tolerance to stress, enterprise and Inner drive. An ancilliary finding was that there was a 
Page 3 of 4

marked difference between public and private executive leaders with regard to enterprise and Inner drive to the advantage of the private executive leaders.

Leaders expressing high levels of Inner drive radiate a work-desire and intrinsic motivation that emanates from within them without the need for external influences. They maintain a positive attitude to their occupation and when confronted by problems search for opportunities to meet with new challenges. They are also open to critical analysis and maintain a resilient and constructive reception to personal attacks with an easy ability to sustain focus upon task assignments without being diverted by irrelevant thoughts towards secondary and trivial goals. They derive inspiration and energy from definitive and unambiguous goal objects displaying a willingness to develop their leadership attributes in order to achieve required performance levels. Inner drive induces a contextual frontline of transformational leadership predicted a sustainment strategy whereas a passive-avoidant leadership, which appears to be represented by police leadership in the results, predicted a strategy of non-sustainment [20]. Enterprising leadership, built upon sustainable attributes, takes great steps to relieve subordinates, and peers, of work stress thereby elevating the general tolerance to stress: the tactic of establishing a level of high-quality leader-member exchange, leadership based upon ethics and rightfulness influenced to a marked extent the tolerance to work stress of employee and general perception of work stress [21]. Leaders presenting high tolerance to stress and high popularity ratings have been shown to be deficit in determination, inner drive and enterprise [22].

From the present findings, an issue that rears itself with regard to police leadership pertains to the extent to which presiding policeleaders have benefitted from leadership educational programs and/or the suitability of those programs for the group in question. The career occupation of policing itself adduces to a complex interaction of social, political and administrative assignments with expected performance in a myriad of often difficult situations and the leadership demands emanating from these levels of complexity, and stress, must apply immeasurable pressures upon individuals. Compared to different types of civil leadership and executive positions, the seriousness of leadership demands exerted by the police corps must be excessive. Yet, with the present reference to just three personal attributes, Inner drive, Tolerance to stress and Enterprise, a markedly lower expression was obtained among the police leadership. The necessity for enterprise development and incorporation with leader roles is stipulated over a wide range of occupational features, including governance, environmental management, security risk management and organizational resilience [23-25]. The opportunities for building Inner drive within leadership are abundant: for example, it been found that autonomous motivation (intrinsic, Inner drive) and an autonomysupportive implementations of coaching models based upon selfdetermination programs [26] predicted positively the proximal transference of attribute (i.e., immediately after the training program) and perception of an autonomy-supportive climate in the sports club predicted positively the distal transference (i.e., one year after the training program). It appears that controllable occupational factors contribute markedly to Tolerance to stress: among military personnel operations it was shown that self-reported stressors arose from work parameters that involved low personnel provision and adequacy, extra duties/administrative tasks, rotating shift work, and long hours on-thejob.

\section{Limitations}

The major limitation to the present involves the situation that a relatively limited number of police leaders $(n=106)$ is compared with large numbers of leaders from private enterprise $(n=828)$ and public administration $(\mathrm{n}=822)$.

\section{References}

1. Gibson A, Villiers P (2006) Leading for Those we Serve. The Police Leadership Qualities Framework. Bramshill, Centrex, England.

2. Axelrod RH (2010) Terms of Engagement. New Ways of Leading and Changing Organizations. Berret-Koehler Publishers Inc, San Francisco, CA, USA.

3. Dobby J, Anscombe J, Tuffin R (2004) Police Leadership: Expectations and Impact. Home Office Online Report, Home Office, Research, Development and Statistics Directorate, Great Britain, UK.

4. Brescoll VL, Dawson E, Uhlmann EL (2010) Hard Won and Easily Lost: The Fragile Status of Leaders in Gender-Stereotype-Incongruent Occupations. Psychol Sci 21: 1640-1642.

5. Ricciardi RM, Akerman J, Eerikäinen P, Ambjörnsson A, Arntén AAC, et al. (2014) Understanding Group and Leader (UGL) trainers' Personality Characteristics and Affective Profiles. Front Psychol 5: 1191.

6. Loiser GF, Koestner R (1999) Intrinsic Versus Identified Regulation in Distinct Political Campaigns: The Consequences of Following Politics for Pleasure Versus, Personal Meaningfulness. Pers Soc Psychol Bull 25: 287-298.

7. Kirkhaug R (2009) Antecedents of Role Conflict in ComplianceEnhancing Organizations. Psychol Rep 105: 1113-1125.

8. Chappelle WL, McDonald KD, Prince L, Goodman T, Ray-Sannerud BN, et al. (2014) Symptoms of Psychological Distress and Posttraumatic Stress Disorder in United States Air Force "drone" Operators. Mil Med 179: 63-70.

9. Violanti JM (2011) Police Organizational Stress: The Impact of Negative Discipline. Int J Emerg Ment Health 13: 31-36.

10. Cooper CL, Cartwright S (1994) Healthy Mind; Healthy organization - A Practive Approach to Occupational Stress. Human Relations 47: 455-471.

11. Thelwell RC, Wagstaff CR, Chapman MT, Kenttä G (2016) Examining Coaches' Perceptions of How Their Stress Influences the Coach-Athlete Relationship. J Sports Sci 8: 1-12.

12. Hernández Baeza A, Araya Lao C, García Meneses J, González Romá V (2009) Leader Charisma and Affective Team Climate: The Moderating Role of the Leader's Influence and Interaction. Psicothema 21: 515-520.

13. Judge TA, Piccolo RF, Kosalka T (2009) The Bright and Dark Side of Leader Traits: A Review and Theoretical Extension of the Leader Trait Paradigm. The Leadership Quarterly 20: 855-875.

14. Archer T, Adolfsson B, Karlsson E (2008) Affective Personality as Cognitive-Emotional Presymptom Profiles Regulatory for Self-Reported Health Predispositions. Neurotox Res 14: 21-44.

15. Tone JL, Salonga A, Bennett J, Strathern L (2015) Hardwiring Improvement to Achieve Exceptional Outcomes: Staff as Leaders Driving Performance. Healthc Manage Forum 28: 82-85.

16. Shaufel MA, Nodrehaug JE, Malterud K (2011) Hope in Action-Facing Cardiac Death: A Qualitative Study of Patients with Life Threatening Disease. Int J Qual Stud Health Well-being 6: 5917.

17. Kjoller H (2016) Tiger: Testimony from Police Officers who Dared Roar From. Fri Tanke Förlag, Stockholm, Sweden.

18. Yukl G (1989) Managerial Leadership: A Review of Theory and Research. J Manag 15: 251-289.

19. Archer T, Jansson B, Olsen K (2015) Effect of Age upon Leadership Attributes from Recruitment Instrument: A Selective Developmental Trajectory. Clin Exp Psychol 1: 106.

20. Aarons GA, Green AE, Trott E, Willging CE, Torres EM, et al. (2016) The Roles of System and Organizational Leadership in System-Wide 
Citation: Arnten AA, Jansson B, Olsen K, Archer T (2017) Self-reported Attributes of Police-chiefs Compared to Civil Leadership: Inner drive, Tolerance to stress and Enterprise. J Forensic Res 8: 367. doi:10.4172/2157-7145.1000367

Page 4 of 4

Evidence-Based Intervention Sustainment: A Mixed-Method Study. Adm Policy Ment Health. 43:991-1008.

21. Zhou H, Jin M, Ma Q (2016) Remedy for Work Stress: the Impact and Mechanism of Ethical Leadership. Cent Eur J Public Health 23: 152-156.

22. Van Mart M (2011) Dynamics of Leadership in Public Service: Theory and Practice. Routledge publishers, New York.

23. Petruzzi J, Loyear R (2016) Improving Organisational Resilience through Enterprise Security Risk Management. J Bus Contin Emer Plan 10: 44-56.
24. Roth CJ, Lannum LM, Joseph CL (2016) Enterprise Imaging Governance: HIMSS-SIIM Collaborative White Paper. J Digit Imaging 29: 539-546.

25. Tang SY, Li PH, Fryxell GE, Lo CW (2015) Enterprise-Level Motivations, Regulatory Pressures, and Corporate Environmental Management in Guangzhou, China. Environ Manage 56: 777-790.

26. Stenling A, Tafvelin S (2016) Transfer of Training After an Organizational Intervention in Swedish Sports Clubs: A Self-Determination Theory Perspective. J Sport Exerc Psychol 38: 493-504. 